\title{
Studies on Adsorption Characteristics of Corn Cobs Activated Carbon for the Removal of Oil and Grease from Oil Refinery Desalter Effluent in a Downflow Fixed Bed Adsorption Equipment
}

\author{
Chinenye Adaobi Igwegbe ${ }^{1 *}$, Chinedu Josiah Umembamalu ${ }^{1}$, Emmanuel Ugochukwu Osuagwu ${ }^{1}$, Stephen N. Oba ${ }^{1}$, \\ Lovet N. Emembolu ${ }^{1}$
}

${ }^{1}$ Department of Chemical Engineering, Nnamdi Azikiwe University, Awka, NIGERIA

*Corresponding Author: ca.igwegbe@unizik.edu.ng

Citation: Igwegbe, C. A., Umembamalu, C. J., Osuagwu, E. U., Oba, S. N. and Emembolu, L. N. (2021). Studies on Adsorption Characteristics of Corn Cobs Activated Carbon for the Removal of Oil and Grease from Oil Refinery Desalter Effluent in a Downflow Fixed Bed Adsorption Equipment. European Journal of Sustainable Development Research, 5(1), em0145. https://doi.org/10.29333/ejosdr/9285

\section{ARTICLE INFO}

Received: 1 Jul. 2020

Accepted: 24 Aug. 2020

\begin{abstract}
The discharge of oil and grease $(\mathrm{O} \& \mathrm{G})$ containing effluent without treatment may contaminate the aquatic environs and freshwater. The removal of $O \& G$ from simulated refinery desalter effluent (SRDE) by activated carbon (AC) originated from chemical activation/carbonization of corn cobs (CCs) was investigated through fixed-bed column studies. The corn cobs activated carbon (CCAC) was characterized to determine its physicochemical properties, and the functional groups presently active on it partaking in the column adsorption process. The CCAC size (150, 300 and $600 \mu \mathrm{m})$, initial adsorbate concentration (200, 300 and $400 \mathrm{mg} / \mathrm{L})$, and bed height $(100,200$ and $300 \mathrm{~mm})$ were varied to observe their influence on the adsorption of O\&G and breakthrough time $(\tau)$ at a constant flow rate of $10.5 \mathrm{~mL} / \mathrm{min}$ in a $10 \mathrm{~mm}$ diameter column of length: $60 \mathrm{~mm}$. The removal of O\&G from SRDE was inspected using the Bohart-Adams (B-A) and Yoon-and-Nelson (Y-N) kinetic models. Breakthrough time and \%O\&G removal decreased with increasing CCAC particle size and feed concentration and improved with rising bed height $(\mathrm{BH})$. The void fractions $(\varepsilon)$ at BHs of 100, 200 and $300 \mathrm{~mm}$ were $0.0247,0.0124$ and 0.0082 , respectively. The ideal residence time $\left(t_{R}\right)$ was $4.49 \mathrm{~min}$. The B-A model yielded the highest degree of fit to the data than the Y-N model with $\mathrm{R}^{2}$ within 0.8217 and 0.9771 . This means that the B-A model can be used to predict the breakthrough curve of any desired values for the present study. This work also revealed that CCs could be packed in a fixed-bed column for $O \& G$ reduction from refinery desalter effluent.
\end{abstract}

Keywords: fixed bed column, oil and grease, breakthrough curve, desalter effluent, crude oil, voidage

\section{INTRODUCTION}

The permissible level for oil and grease $(O \& G)$ by WHO in refinery effluent is $10 \mathrm{mg} / \mathrm{L}$ (Umembamalu et al., 2020). These contaminants may appear in forms such as emulsified oil, free oil, or like a coating or suspended matter (Al-Malack and Siddique, 2013). Oil and grease is used to sum up the total hydrocarbon (petroleum and its derivatives) pollutants such as naphthenic, aromatic, and paraffinic hydrocarbons pollutants present in water (ABNT, 2003; Boni et al., 2016). Usually, crude refining is the preliminary step in the pretreatment process which aims at subjecting the crude oil to a series of treatments to reduce the contaminants to acceptable levels. In other to remove all these contaminants, the following petroleum pretreatment processes are adopted: crude oil desalting, crude heating, desulphurization, and pre-flashing. The process of crude oil desalting in the refinery will produce liquid effluent that contains oil, grease, salts, mud, and other impurities (Afshin and Toraj, 2008).

This oily waste discharge is responsible for harmful effects such as objectionable odours, undesirable appearance, and flammability on the surface of the receiving water, thus leading to a potential safety hazard. Most importantly, the presence of $O \& G$ in water bodies constitutes a major threat to aquatic life as it consumes dissolved oxygen necessary for aquatic life survival (Islam et al., 2013), and in greater quantities, it limits oxygen transfer (Alade et al., 2011; Facchin et al., 2013). Water pollution has also resulted in diseases and deaths globally (Yalcinkaya et al., 2020; Ighalo and Adeniyi 2020). This work seeks to solve this challenge through the aid of an adsorption column.

Nowadays, there are lots of technologies or methods used successfully for the removal of $O \& G$, they include conventional coagulation, electrocoagulation, membrane distillation, adsorption, filtration, etc. (Adams et al., 2017; 
Ariana et al., 2016; Diraki et al., 2019; Kulkarni, 2016; Kulowiec, 1979; Manilal et al., 2020; Mazumder and Mukherjee, 2011; Pintor et al., 2016; Rahmat et al., 2018; Umembamalu et al., 2020; Yalcinkaya et al., 2020). The choice of adsorption for this research is due to its effective and economical nature regarding the usage of agricultural derived biomass as adsorbents with neither little nor economic value (Bharathi and Ramesh, 2013; Choi, 2019; Goel et al., 2005; Onyechi, 2014; Umembamalu et al., 2020). Agricultural biomass are renewable and also possess low inorganic content (Younis et al., 2020). Adsorption method is the most efficient preferred and established method for the removal of organic and inorganics (Ighalo et al., 2020; Igwegbe et al., 2018, 2020; Rashed, 2013). Adsorption is also advantageous due to the involvement of simple design and low investment cost (Ahmadi and Igwegbe, 2020).

The adsorbent selected for this research is very accessible and affordable since it is obtained from corn cobs which is an agricultural biomass; it does not compete with human and animal survival since it is not a source of food. Numerous agricultural wastes' ACs such as rice husks (Umembamalu et al., 2020), banana peels (Borhan et al., 2014), carbonised grass (Rahmat et al., 2017), and sugarcanne bagasse (Nadzirah et al., 2015) have been harnessed for the reduction of $O \& G$ in effluents even commerically obtained granular and powdered ACs (Al-Kaabi et al., 2019; Fulazzaky and Omar, 2012; Grieves et al., 1980). Also, raw agricultural wastes such as sugarcane bagasse (Boni et al., 2016; Hamid et al., 2016) and banana pith (Hamid et al., 2016; Sasirekha et al., 2018), and plants such as neem, Posidonia oceanica (Jmaa and Kallel, 2019). and curry leaves (Sasirekha et al., 2018) have been used for O\&G removal from effluents. In the present work, corn cobs (CCs) were transformed to AC. CCs have been used successfully for adsorption of pollutants (Adams et al., 2017; Choi and Yu, 2019; Janani et al., 2019; Malode and Mamilwar, 2017; Muthusamy and Murugan, 2016; Norozi and Haghdoost, 2016; Sharma et al., 2019; Vu et al., 2018). As biomass, CCs have desirable properties such as porous structure, and chemical reactive groups (e.g. carboxy, hydroxyl) essential in sequestration of contaminants from effluents (Dai et al., 2018). But no research has been performed for the removal of $O \& G$ from desalter effluent via CCs in column studies. This study adopts the use of continuous column adsorption for $O \& G$ removal over the more common batch mode adsorption as it provides the most realistic application of adsorption activites (Rao, 2011), especially in water management. The impact of particle size, bed height $(\mathrm{BH})$ and feed concentration at 10.5 $\mathrm{mL} / \mathrm{min}$ on breakthrough time $(\tau)$ were examined. It is also necessary to determine the best CCAC size since its has a great effect on column adsorption studies. Smaller sizes create bubble effects and will shift a fixed bed to a fluidized bed. The data generated from the variation of the various process variables in the column adsorption process will give valuable perceptions into the adsorption mechanism and pathways of the reaction (Albadarin et al., 2012; Nwabanne and Igbokwe, 2012). Furthermore, the experimental data were modeled with the Bohart-Adams (B-A) alongside the Yoon-and-Nelson (YN) kinetic models.

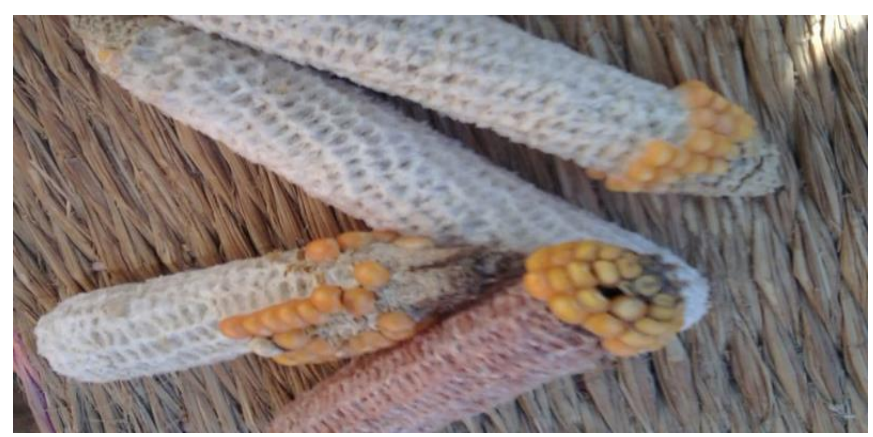

Figure 1. Image of CCs

\section{EXPERIMENTAL METHODS}

\section{Corn Cobs (CCs) and Reagents Collection}

The CCs (Figure 1) were obtained from corn farmers in Awka, Nigeria. They were meticulously cleaned with distilled water and subsequently dried for $8 \mathrm{~h}$ at $105^{\circ} \mathrm{C}$ with the use of oven. Thereafter, their sizes were reduced with a mortar and pestle, sieved to CCs sizes of between 1-2 mm with a molecular sieve and stored in a container.

Analytical graded chemicals were used as reagents for the experiment. A simulated refinery desalter effluent (SRDE) was prepared using deionized water $(25 \mathrm{~L})$, calcium chloride $(\mathrm{CaCl})$, sodium chloride $(\mathrm{NaCl})$, and crude oil. Freshly prepared solution of sodium hydroxide $(\mathrm{NaOH})$ was also used for the activation of the CCs.

\section{Chemical Activation and Carbonization of the CCs}

Firstly, the stored CCs were redried. A solution of $\mathrm{NaOH}$ was poured into $100 \mathrm{~g}$ of the CCs (ratio = 1:1). The sample was then heated in a water bath at $80^{\circ} \mathrm{C}$ with the shaker set at the speed of $150 \mathrm{rpm}$. Later, it was dehydrated at $120^{\circ} \mathrm{C}$ for $24 \mathrm{~h}$. The impregnated CCs was carbonized under $\mathrm{N}_{2}$ flow of gas for $3.5 \mathrm{~h}$ at $500^{\circ} \mathrm{C}$ in a muffle furnace to produce charcoal. The AC, having been conditioned to normal temperature, was rewashed several times with warm distilled water until $\mathrm{pH}$ of 6 - 7 was attained to remove any remains of $\mathrm{NaOH}$, passed through a filter paper (Whatman No. 1) and dried for $8 \mathrm{~h}$ at $115^{\circ} \mathrm{C}$. The produced corn cobs activated carbon (CCAC) size was reduced and separated in varying CCAC particle sizes (150, 300 , and $600 \mu \mathrm{m}$ ) with the use of sieves and airtighted.

\section{Properties of the CCAC}

Physicochemical characteristics of the CCAC were verified. The moisture content (MC) was obtained by drying $10 \mathrm{~g}$ of the AC placed in a crucible in the oven at $105^{\circ} \mathrm{C}$ for $4 \mathrm{~h}$. (Rengaraj et al., 2002). The percentage of moisture content (\%MC) was determined using Eq. (1):

$$
\% M C=\frac{\text { loss in weight on drying }(g)}{\text { initial sample weight }(g)} \times 100
$$

The porosity ( $\eta$ ) of the CCAC was determined using Eq. (2):

$$
\eta=\frac{V_{v}}{V_{t}}
$$




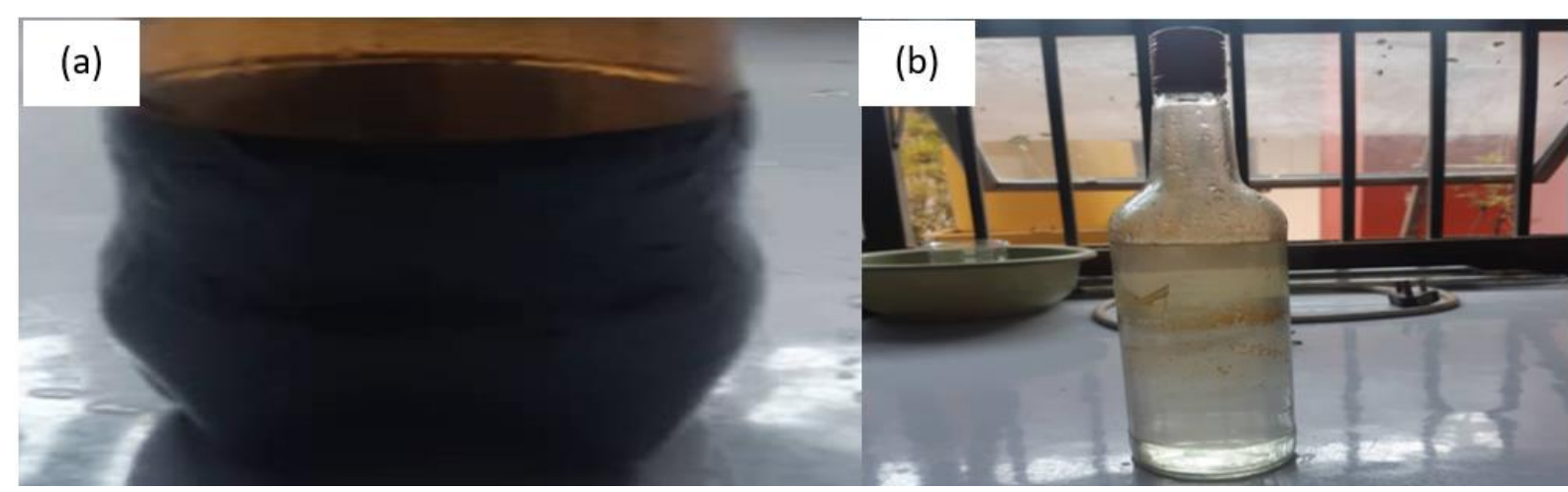

Figure 2. (a) The sample of crude oil used, and (b) the simulated desalter effluent

Where $V_{v}=$ volume of void $\left(\mathrm{cm}^{3}\right)=V_{t}$, total volume used for the experiment $\left(\pi r^{2} h\right)-V_{s}$, volume of CCAC used $\left(\frac{M s}{G s \rho w}\right) ; r$ is the cylinder's radius in $\mathrm{cm} ; G_{s}$ is the specific gravity of the CCAC $=0.365 ; M_{s}$ is the weight of CCAC in $g, \rho_{w}$ is the density of water in $\mathrm{g} / \mathrm{mL}$, and $h$ is the height of cylinder used in $\mathrm{cm}$.

The bulk density (BD) was determined by drying the AC in an oven at $105^{\circ} \mathrm{C}$ for $1 \mathrm{~h}$. The weight of the $\mathrm{AC}$ that filled the $25 \mathrm{~cm}^{3}$ empty density was taken. The bulk density was computed using Eq. (3) (Devi et al., 2012):

$$
B D=\frac{\text { weight of powder taken in bottle of } 25 \mathrm{~cm} 3}{25}
$$

ASTM D2866-94 was used to evaluate the ash content (AHC\%) of the CCAC by first heating the CCAC placed in a crucible in a muffler furnace at $500^{\circ} \mathrm{C}$. The heated CCAC was cooled and the weight taken. $1 \mathrm{~g}$ CCAC was put into the crucible and reweighed. Then, it was placed in the muffler furnace and the temperature let to increase to $500^{\circ} \mathrm{C}$ and the CCAC was removed, allowed to cool to room temperature and reweighed again. The AHC\% was estimated via Eq. (4):

$$
\text { AHC\% }=\frac{\text { Ash weight }(g)}{\text { Oven dryweight }(g)} \times 100
$$

For the pH evaluation, $2 \mathrm{~g}$ CCAC was poured into a beaker, $20 \mathrm{~mL}$ of distilled water was introduced and the mixture heated under reflux for $15 \mathrm{~min}$. Then, the $\mathrm{pH}$ of the sample was taken after the sample was let to stabilize (Egwaikhide et al., 2007).

\section{Preparation of Desalter Effluent}

$1000 \mathrm{~mL}$ de-ionized water was measured into $1000 \mathrm{~mL}$ beaker. Thereafter, $50 \mathrm{~g}$ of $\mathrm{NaCl}$ and $5 \mathrm{~g}$ of $\mathrm{CaCl}$ were measured with the aid of an electric weighing balance and was then poured into a volumetric flask of $1000 \mathrm{~mL}$. After this, the deionized water was gradually poured into the flask and mixed properly until the $1000 \mathrm{~mL}$ mark was reached. $400 \mathrm{~mL}$ brine solution was measured out and introduced back into the 1000 $\mathrm{mL}$ beaker. Thereafter, $300 \mathrm{mg} / \mathrm{L}$ of crude oil (with properties: API gravity $=17.8$, density $=0.963 \mathrm{~g} / \mathrm{cm}^{3}$ at $15^{\circ} \mathrm{C}$, vapour pressure $=7 \mathrm{kPa}$, flash point $=97^{\circ} \mathrm{C}$, pour point $=-10^{\circ} \mathrm{C}$, kinematic viscosity $=81.32 \mathrm{cSt}$ and specific gravity $=0.959$ at $60^{\circ}$ F) (Figure 2a) was injected into the $400 \mathrm{~mL}$ brine solution with the aid of a syringe. The mixture was then stirred using the magnetic stirrer at $15000 \mathrm{rpm}$ for $15 \mathrm{~min}$. The remaining $600 \mathrm{~mL}$ brine solution was then added and stirred at a reduced speed of $11000 \mathrm{rpm}$ for additional $5 \mathrm{~min}$. The simulated desalter effluent (Figure 2 b) was then poured into a collection bottle (effluent bottle). This process was repeated for other concentrations of the feed ( 200 and $400 \mathrm{mg} / \mathrm{L}$ ). The total time for the preparation of effluent is within the range of $45 \mathrm{~min}$ to $1 \mathrm{~h}$.

\section{Column Adsorption Experiment}

Adsorption of O\&G on CCAC was studied using packed adsorption column of $10 \mathrm{~mm}$ inside diameter and $600 \mathrm{~mm}$ length which was loaded with CCAC of varying bed heights $(100,200$, and $300 \mathrm{~mm})$ having a mesh at the bottom of the column. The containing vessel having the effluent feed was kept at a high elevation and a peristaltic pump (pump model: BQ50-IJ-A, LP-BQ50-1J miniature peristaltic pump) (Figure 3a) with flow rate specification of $0.0002-20 \mathrm{~mL} / \mathrm{min}$, power supply (pump): DC 12V/10W, power supply (adapter): AC 90V260V/10W, operating temperature: $0-40{ }^{\circ} \mathrm{C}$, drive dimensions $(\mathrm{L} \times \mathrm{W} \times \mathrm{H}): 135 \times 72 \times 72(\mathrm{~mm})$, controller dimensions $(\mathrm{L} \times \mathrm{W} \times \mathrm{H})$ : $105 \times 50 \times 16(\mathrm{~mm})$ and drive weight: $0.5 \mathrm{~kg}$ was used to drive the feed into the adsorption column set up (Figure 3b) at a constant flow rate of $10.5 \mathrm{~mL} / \mathrm{min}$ in downflow mode. The CCAC size (150-600 $\mu \mathrm{m})$, feed concentration or strength (200, 300 and $400 \mathrm{mg} / \mathrm{L}$ ), and bed height (100, 200 and $300 \mathrm{~mm}$ ) were varied to observe their influence on O\&G removal (\%) and breakthrough time at a constant flow rate (FR) of $10.5 \mathrm{~mL} / \mathrm{min}$. This flow rate was achieved by adjusting the remote sensor flow rate to a desired rate on the peristaltic pump. The effluent samples were taken at 5 min intervals from the column's exit. The effluent samples collected were tested for absorbance using a UV-visible spectrophotometer at $980 \mathrm{~nm}$.

The breakthrough curve was plotted as per Seader et al., (2011). The schematic representation of the fixed bed adsorption experiment is shown in Figure 4 (which was drawn using the Microsoft Visio).

\section{Modelling of Column Study Results}

The Bohart-Adams (B-A) model, extensively used in fixedbed columns design (Song et al., 2015; Dutta and Basu, 2013) was employed to predict the character of the column. The mathematically relationship can be given as (Swarup and Mishra, 2015; Song et al., 2015):

$$
\operatorname{Ln}\left(\frac{C_{t}}{C_{o}}\right)=K_{B A} C_{o} t-K_{B A} N_{o}\left(\frac{Z}{U_{0}}\right)
$$

Where $C_{o}(\mathrm{mg} / \mathrm{L})=\mathrm{SRDE}$ feed strength, $C_{t}(\mathrm{mg} / \mathrm{L})=$ treated SRDE strength, $K_{B A}(\mathrm{~L} / \mathrm{mg} \min )=\mathrm{B}-\mathrm{A}$ constant of kinetics, $t$ $(\mathrm{min})=$ time of flow, $U_{\mathrm{o}}=$ Superficial velocity $(\mathrm{cm} / \mathrm{min}), N_{\mathrm{o}}$ 


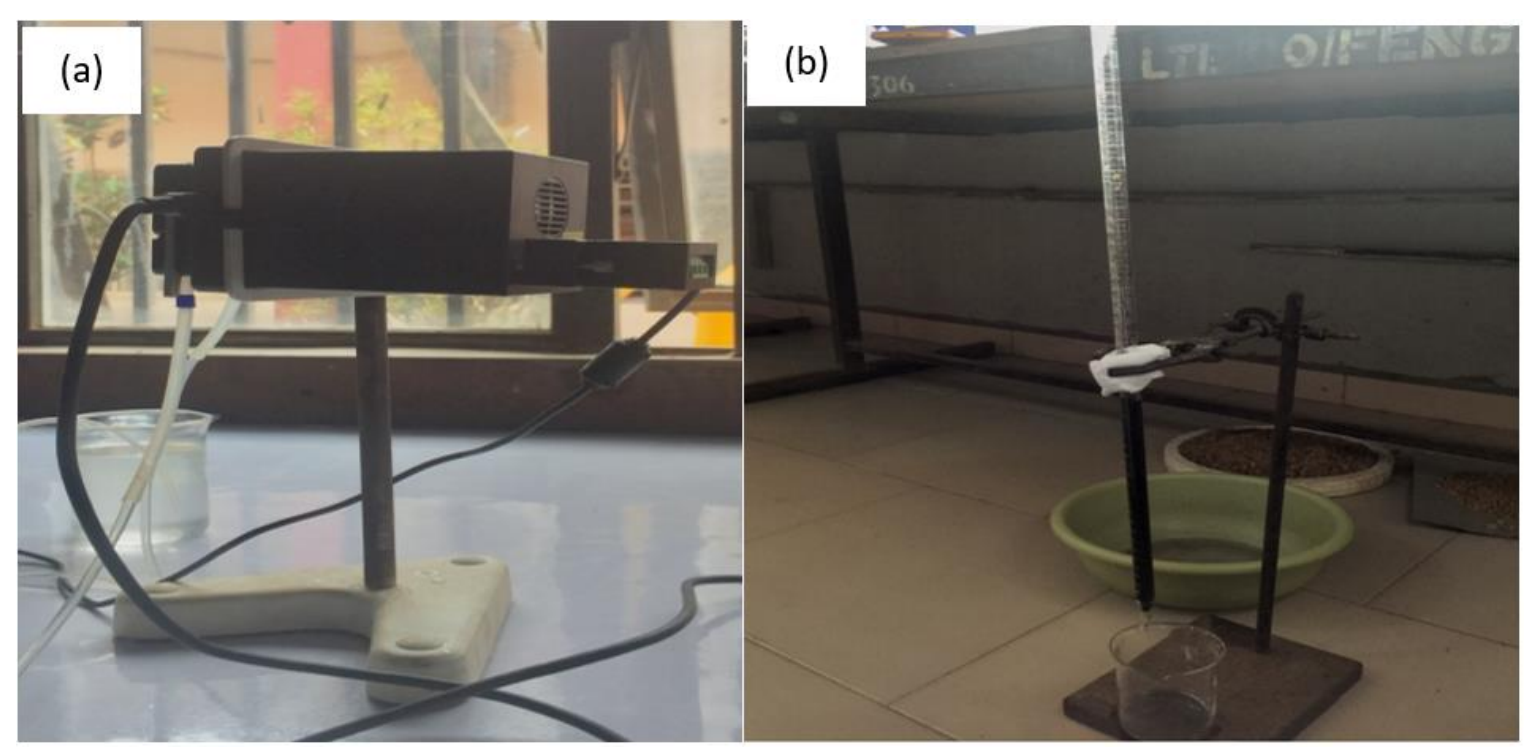

Figure 3. (a) the peristaltic pump, (b) the column adsorption setup used in this work

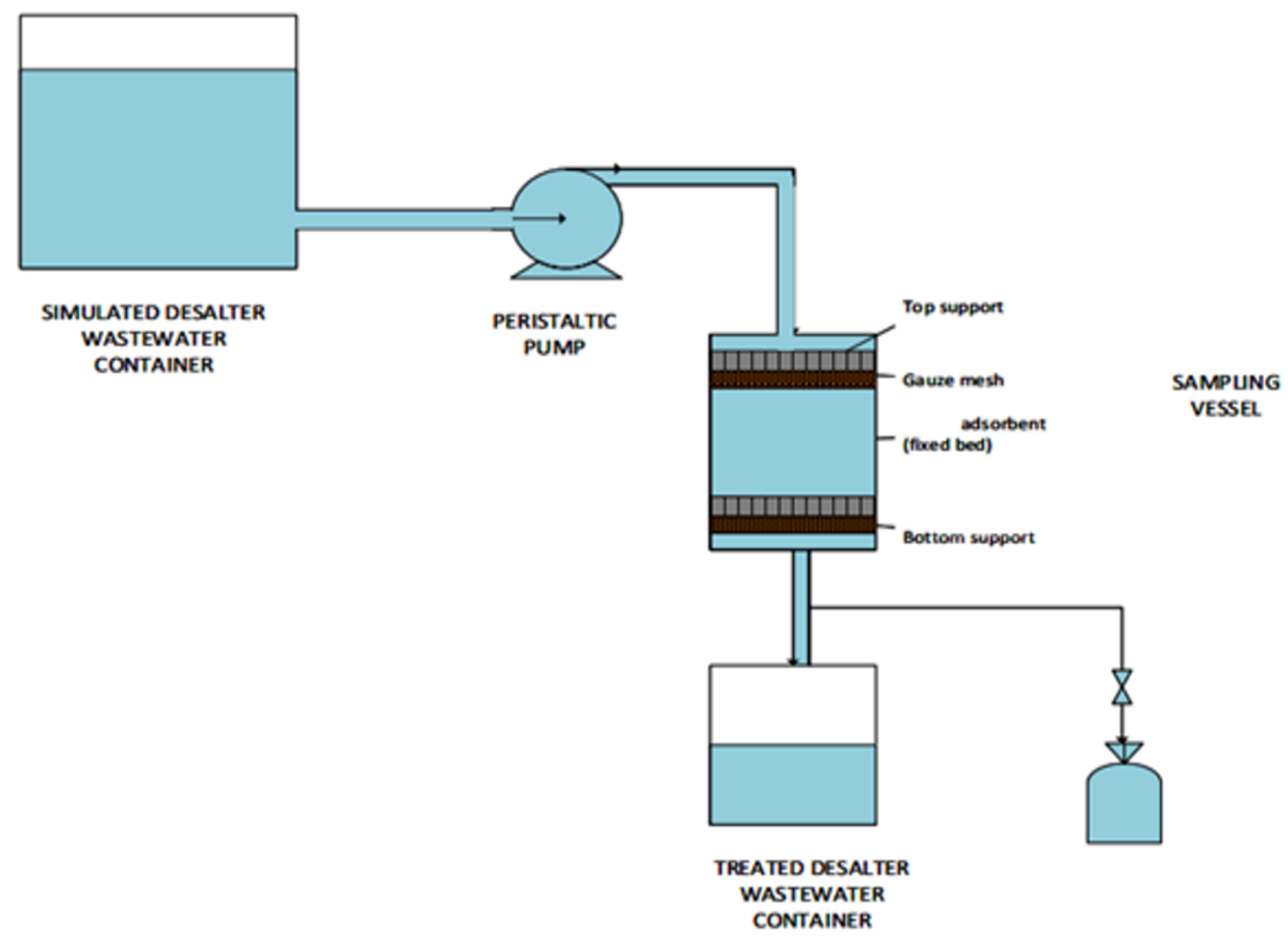

Figure 4. Diagrammatic depiction of the fixed-bed adsorption experiment

$(\mathrm{mg} / \mathrm{L})=$ concentration of saturation, and $z(\mathrm{~cm})=\mathrm{BH}$ of the column.

The saturation concentration $\left(N_{\mathrm{o}}\right)$ and kinetic constant $\left(K_{B A}\right)$ were evaluated from the intercept and slope of $\operatorname{Ln}\left(C_{t} / C_{0}\right)$ versus $t$ which also gives $\mathrm{R}^{2}$ (correlation coefficient) too.

The Yoon-and-Nelson (Y-N) model was applied to the kinetics study of column adsorption by several authors (Akoji, 2019; Kavak and Öztürk, 2004; Nwabanne and Igbokwe, 2012; Sivakumar and Palanisamy, 2009). Mathematically, this model is expressed thus (Akoji, 2019; Bulgariu and Bulgariu, 2013):

$$
\operatorname{Ln}\left(\frac{C_{t}}{C_{o}-C_{t}}\right)=k_{N Y} t-\tau k_{N Y}
$$

Where, $C_{o}(\mathrm{mg} / \mathrm{L})=$ SRDE feed strength; $C_{t}(\mathrm{mg} / \mathrm{L})=$ treated SRDE strength; $K_{N Y}\left(\mathrm{~min}^{-1}\right)=$ rate constant; $\tau(\min )=$ period of breakthrough; $t=$ sampling period ( $\min )$.

Ploting Ln $\left(C_{t} /\left(C_{0}-C_{t}\right)\right)$ against $t$ yields the rate constant $\left(K_{Y N}\right)$, time required for breakthrough $(\tau)$ and and correlation coefficients $\left(\mathrm{R}^{2}\right)$. 
Table 1. Characteristics of the CCAC

\begin{tabular}{cc}
\hline Parameter & Evaluate \\
\hline Moisture & $6.5 \%$ \\
Bulk density (BD) & $0.362 \mathrm{~g} / \mathrm{mL}$ \\
pH & $6.3 \pm 0.2$ \\
Ash content & $5.4 \%$ \\
Porosity & 0.231 \\
\hline
\end{tabular}

Table 2. The FTIR analysis of the CCAC

\begin{tabular}{cccc}
\hline S/N & Peaks $\left(\mathbf{c m}^{-1}\right)$ & Functional group & $\begin{array}{c}\text { Peak } \\
\text { description }\end{array}$ \\
\hline 1 & 894.6 & =C-H bend in alkenes & strong \\
\hline 2 & 1200.2 & C-O in carboxylic acid & strong \\
\hline 3 & $1312.0,1364.2$ & $\begin{array}{c}\text { N-O symmetric stretching in } \\
\text { nitrocompounds }\end{array}$ & intermediate \\
\hline 4 & 1428.8 & $\begin{array}{c}\text { C-C stretch (in-ring) in } \\
\text { aromatics }\end{array}$ & intermediate \\
\hline 5 & 1592.2 & $\begin{array}{c}\text { N-O asymmetric stretching } \\
\text { in nitrocompounds }\end{array}$ & strong \\
\hline 6 & 1651.2 & C=C stretching in alkenes & intermediate \\
\hline 7 & 2057.5 & -C=C- stretch in alkynes & weak \\
\hline 8 & 2892.4 & C-H stretch in alkanes & intermediate \\
\hline 9 & 3332.2 & $\begin{array}{c}\text { O-H stretching in } \\
\text { phenols/alcohols }\end{array}$ & strong \\
\hline
\end{tabular}

\section{RESULTS AND DISCUSSION}

\section{Charactristics of CCAC}

The characteristics obtained for CCAC are stated below (Table 1). Bulk density (BD) specifies the fiber content of the precursor (Baseri et al., 2012). The BD value of $0.362 \mathrm{~g} / \mathrm{mL}$ was measured. The $\mathrm{pH}$ value of the CCAC was observed to be near neutral which are useful for purification of water (Baseri et al., 2012; Igwegbe et al., 2020). The AC with high percentage of fixed carbon will have high capacity of adsorption (Dada et al., 2012); the CCAC has a good percentage of carbon.

The functional groups on the CCAC responsible for $\mathrm{O} \& \mathrm{G}$ adsorption were identified through the FTIR analysis using the Shimadzu 8400S spectrophotometer. The FTIR spectra of the CCAC is displayed in Table 2 and Figure 5 protraying the existence of alcohols, alkenes, alkanes, nitro compounds, aromatics, carboxylic acids and phenols. O-H stretching in phenols and alcohols, a broadband (Igwegbe et al., 2016) was seen; this strong band is necessary in adsorption processes because of the existence of hydrogen bonding (Batool et al., 2018; Zhang et al., 2017).

\section{Adsorption Column Studies}

\section{Breakthrough curves}

Fixed bed adsorber design mainly involves calculating the breakthrough curve (Kavak and Öztürk, 2004; Nwabanne et al., 2011).

Influence of particle size: The impact of the various CCAC particle sizes $(150,300,600 \mu \mathrm{m})$ on the breakthrough curve was investigated at constant $\mathrm{BH}$ : $300 \mathrm{~mm}$, flow rate (FR): $10.5 \mathrm{~mL} / \mathrm{min}$ and feed strength: $300 \mathrm{mg} / \mathrm{L}$ (Figure 6). The breakpoint time, $\tau$ decreased from 475,350 , and $240 \mathrm{~min}$ as the particle size enlarged from 150-600 $\mu \mathrm{m}$,. This was carried out at a breakthrough concentration of $90 \%$, that is $\mathrm{C}_{\mathrm{t}} / \mathrm{C}_{0}=0.9$. Also, it was observed that $150 \mu \mathrm{m}$ particle size was best since it took longer time to attain saturation time than it took 300 and $600 \mu \mathrm{m}$ particle sizes. Hence, it can be recommended for scale-up purposes, whereas, for laboratory-scale, $300 \mu \mathrm{m}$ was selected because $150 \mu \mathrm{m}$ shifted the adsorption column from being a fixed bed to a fluidized bed. Therefore, there was a need for more control to maintain the fixed bed adsorption column at $150 \mu \mathrm{m}$. Increasing the CCAC size decreased the \%removal at different times but $5 \mathrm{~min}$ gave the maximum removal. Similar observation was reported by Umembamalu et al. (2020)

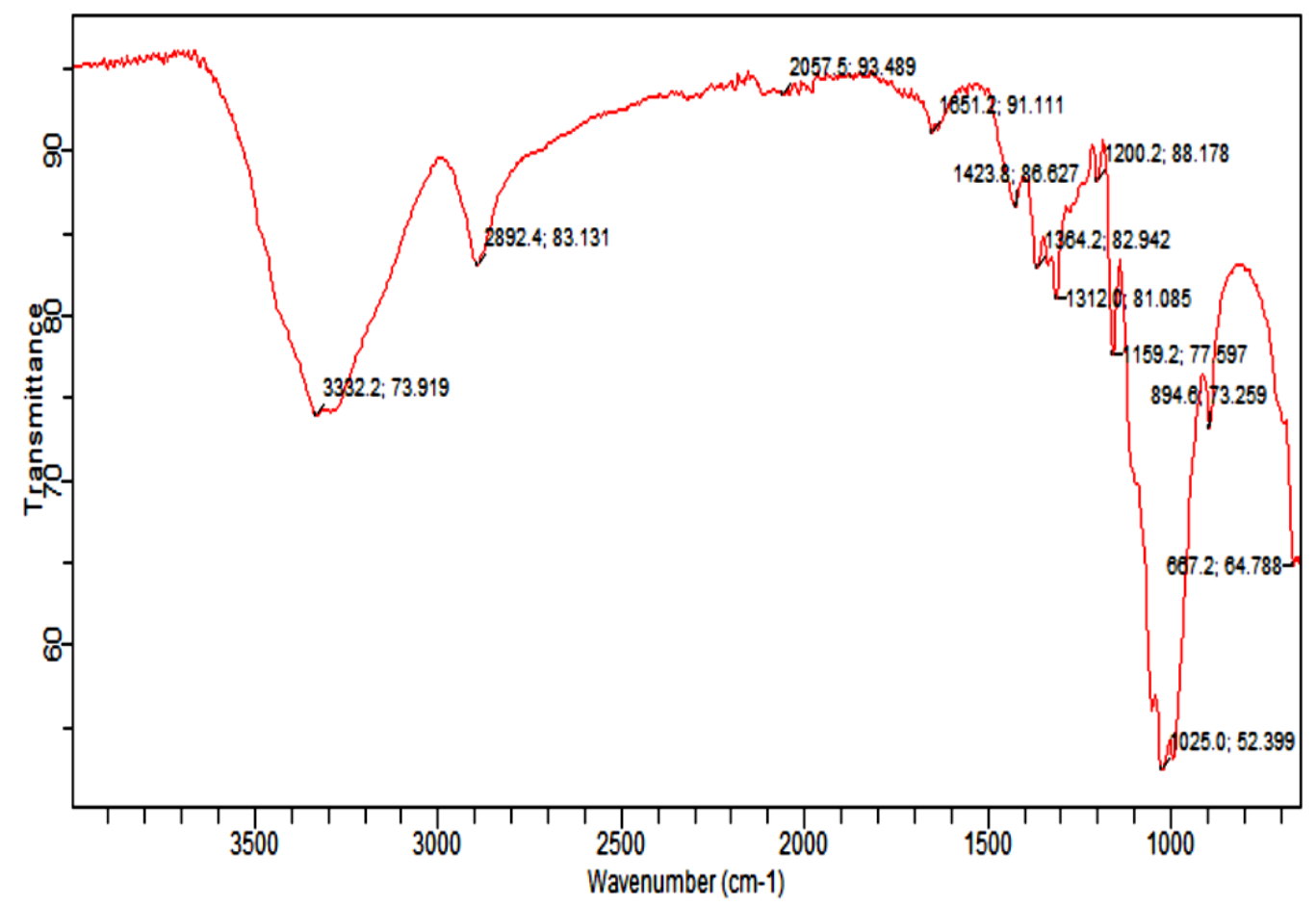

Figure 5. FTIR spectrum of the CCAC 


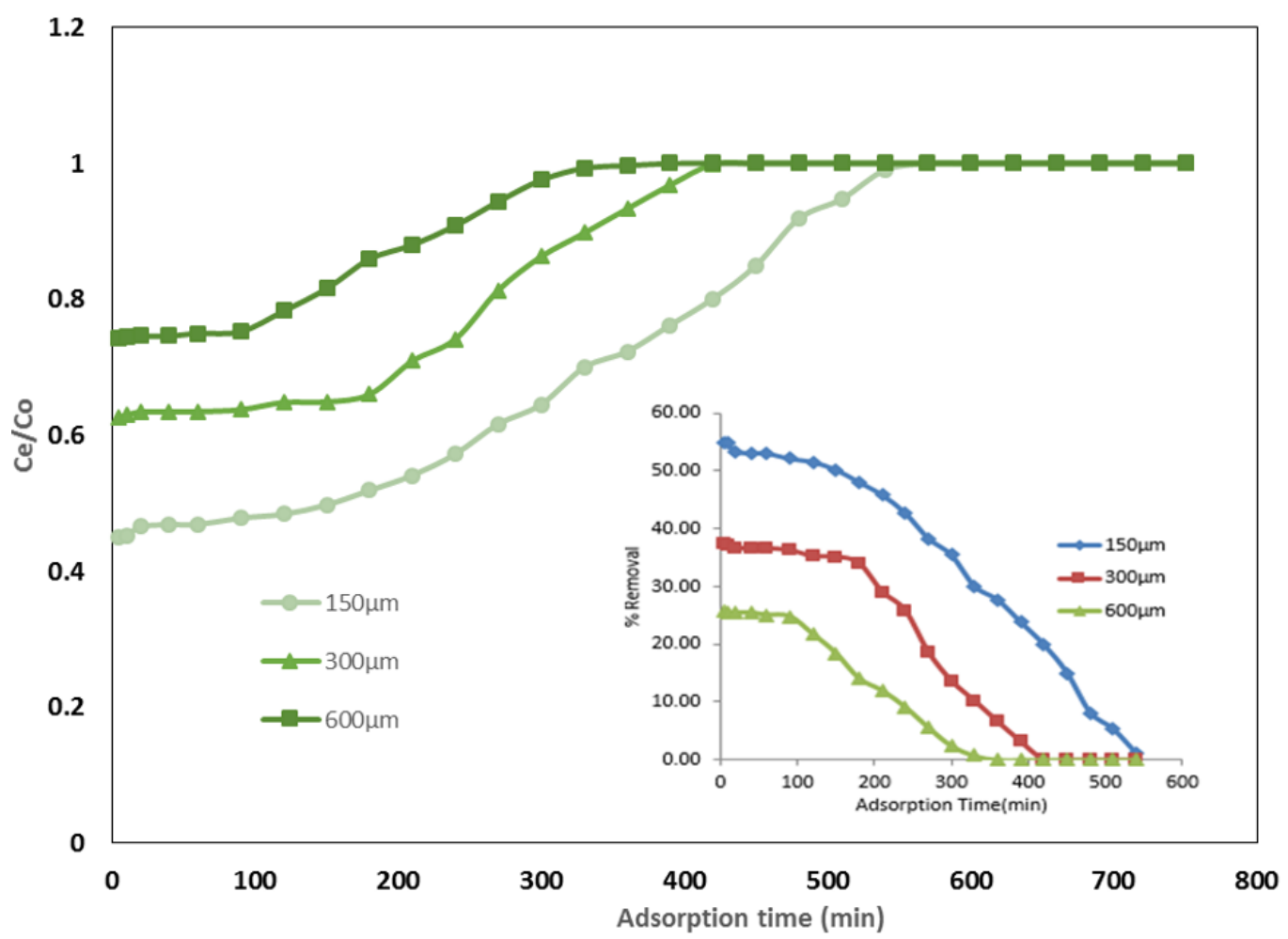

Figure 6. A graph of the effect of particle size on breakthrough curve for $\mathrm{O} \& \mathrm{G}$ onto CCAC $(\mathrm{BH}=300 \mathrm{~mm}, \mathrm{FR}=10.5 \mathrm{~mL} / \mathrm{min}$ and feed strength $=300 \mathrm{mg} / \mathrm{L}$ )

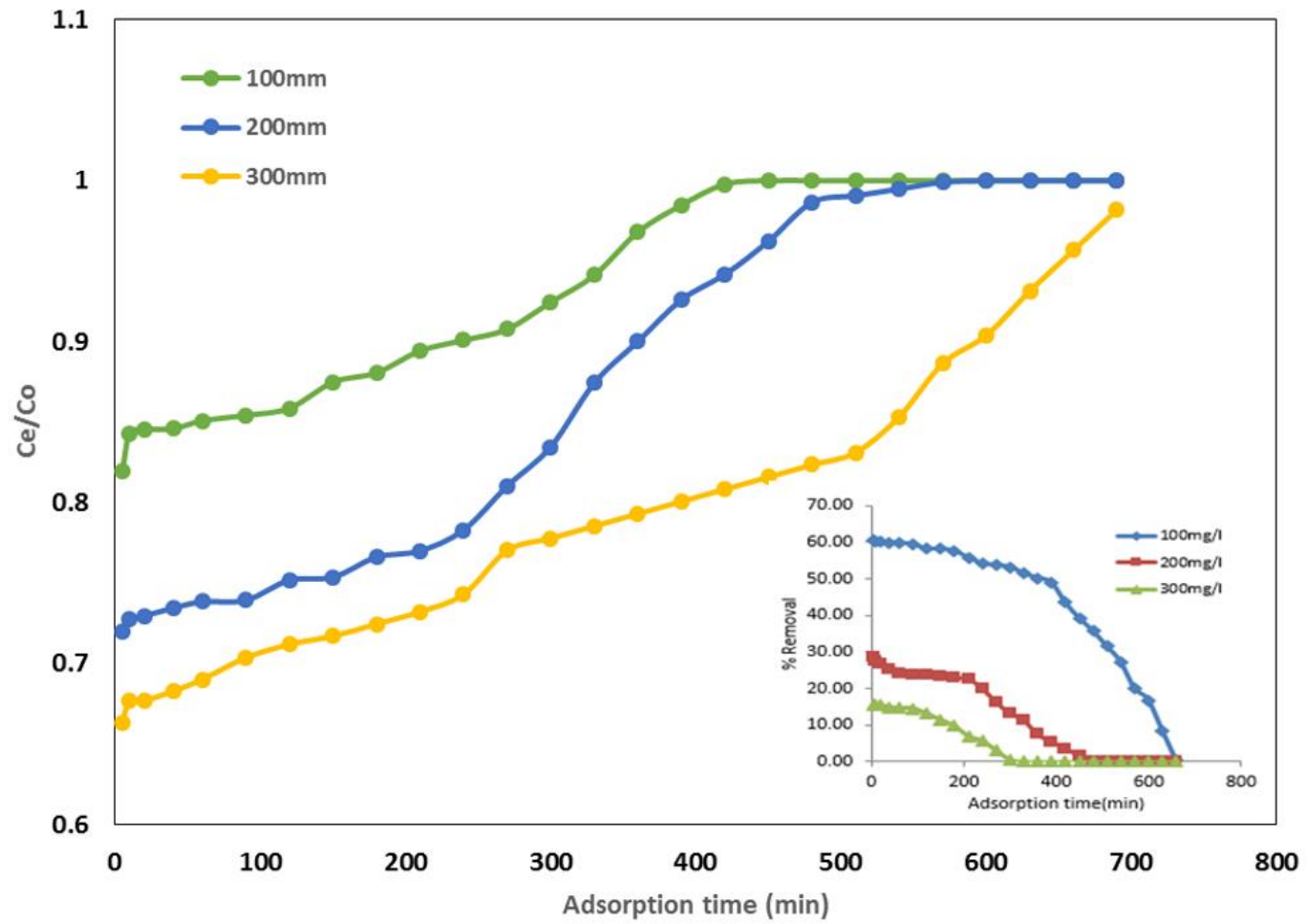

Figure 7. Graph of the impact of $\mathrm{BH}$ on the curve of breakthrough for $\mathrm{O} \& \mathrm{G}$ onto CCAC (CCAC particle size $=300 \mu \mathrm{m}, \mathrm{FR}=10.5$ $\mathrm{mL} / \mathrm{min}$ and feed strength $=300 \mathrm{mg} / \mathrm{L}$ )

for oil and grease removal using rice husks carbon. Maximum removals of $54.93,37.28$ and $25.63 \%$ were obtained when CCAC sizes of 150,300 and $600 \mu \mathrm{m}$, respectively were used. Maximum removal of $54.93 \%$ was obtained at the lowest CCAC size considered (that is, $150 \mu \mathrm{m}$ ).

Influence of bed height (BH): Influence of oil and grease elimination onto CCAC is revealed in Figure 7; $300 \mathrm{~mm} \mathrm{BH}$ required a longer time to attain saturation when related to $\mathrm{BHs}$ of 100 and $200 \mathrm{~mm}$. The \%removal was improved as the BH rose from 100 to $300 \mathrm{~mm}$. Maximum removals of 18.04, 27.97 and $33.66 \%$ were observed at BHs of 100, 200 and $300 \mathrm{~mm}$, respectively at $5 \mathrm{~min}$. In other words, the higher $\mathrm{BH}$ corresponds to a higher amount of active sites and adsorbed oil and grease, and vice versa (Nwabanne and Igbokwe, 2012; 


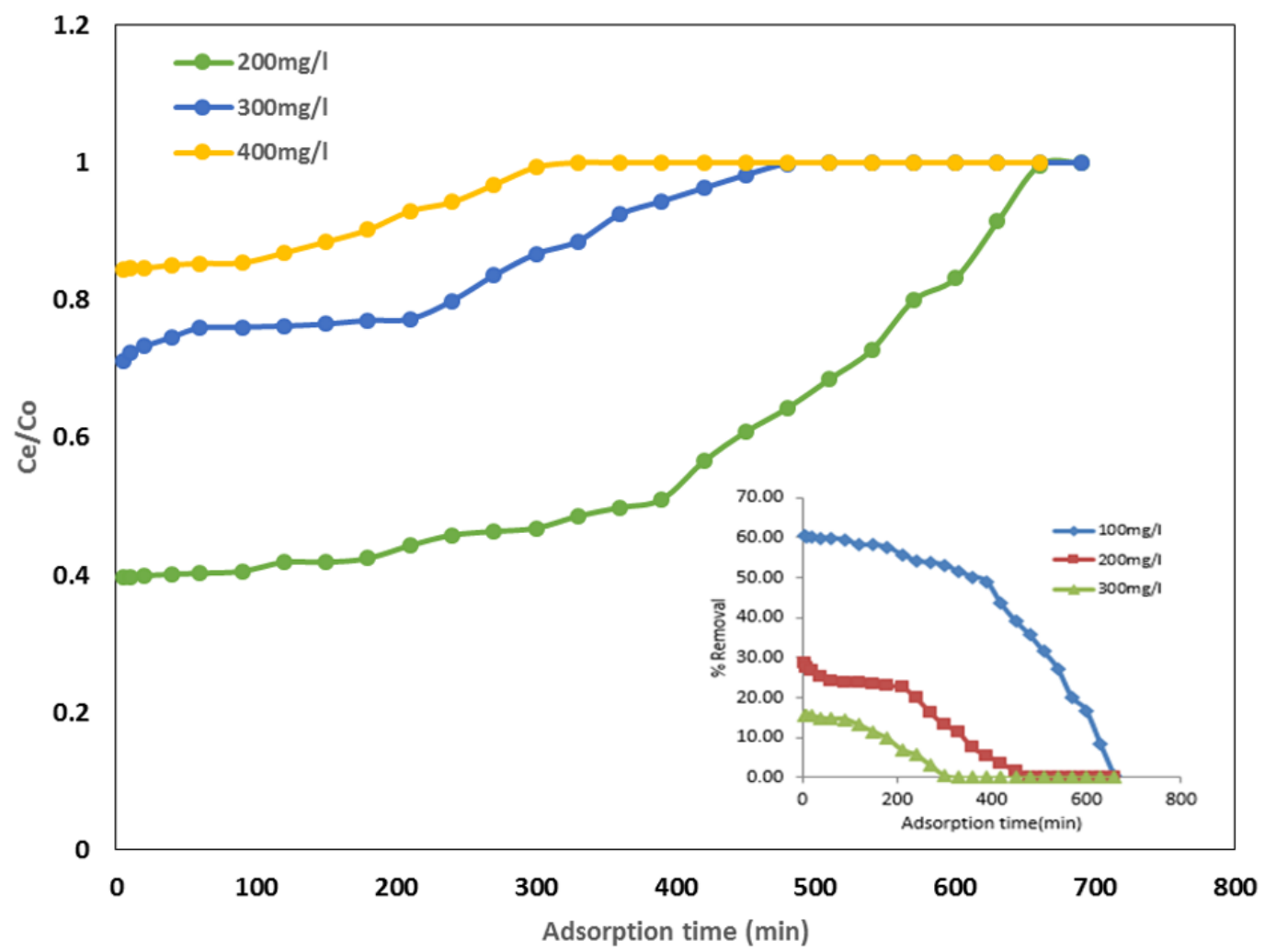

Figure 8. Graph of feed strength on the breakthrough curve for O\&G onto CCAC (CCAC size $=300 \mu \mathrm{m}, \mathrm{BH}=300 \mathrm{~mm}$, and FR $=$ $10.5 \mathrm{~mL} / \mathrm{min})$

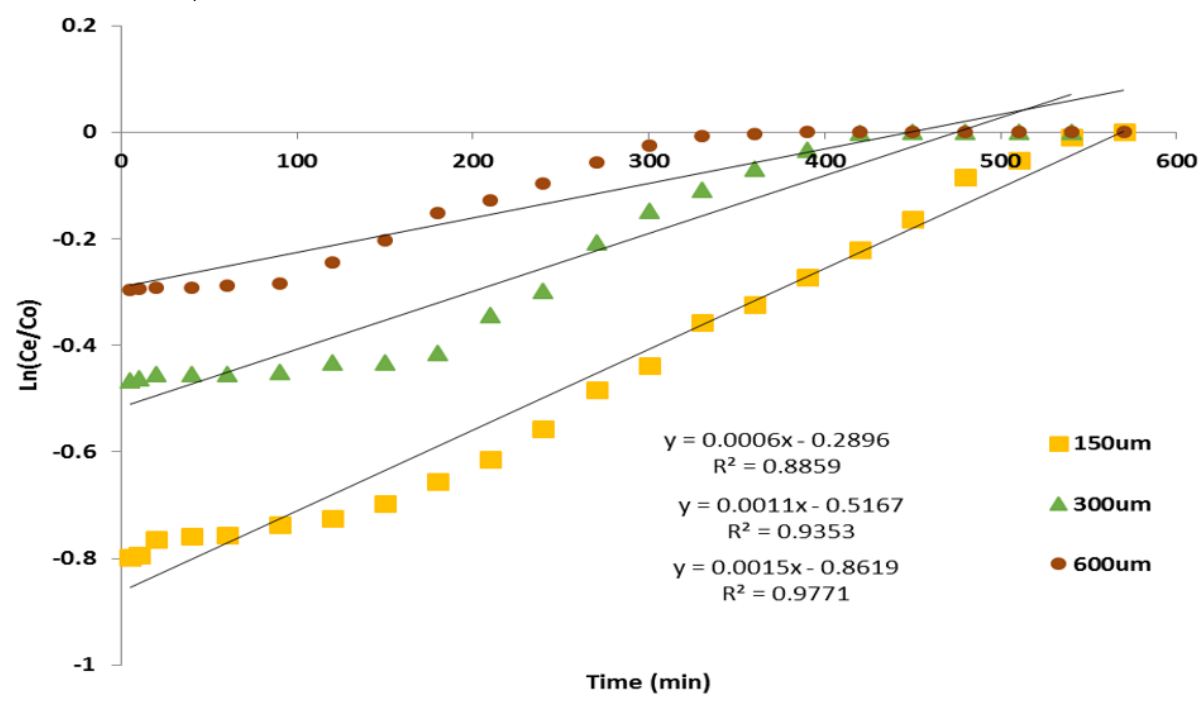

Figure 9. B-A kinetics for O\&G elimination onto CCAC: Particle size

Sivakumar et al., 2010). Similar observations were reported by Hernandez-Eudave et al. (2015), Umembamalu et al. (2020). As $\mathrm{BH}$ rose from 100, 200, and $300 \mathrm{~mm}$, the breakthrough time increased from 390, 480 to $700 \mathrm{~min}$, respectively. This was done using a breakthrough concentration of $90 \%$.

Feed concentration on breakthrough curves: Varying feed strengths (concentrations) (200, 300, and $400 \mathrm{mg} / \mathrm{L}$ ) on the curve of breakthrough were studied at FR: $10.5 \mathrm{~mL} / \mathrm{min}$, particle size: $300 \mu \mathrm{m}$, and BH: $300 \mathrm{~mm}$ (Figure 8). This was done using a breakthrough strength of $90 \%$. The breakthrough time decreased from 620, 300, and 180 min when the inlet feed strength increased from 200, 300, and $400 \mathrm{mg} / \mathrm{L}$. Similar trend was observed by De Franco et al. (2018). Maximum removals of $60.38,28.76$ and 15.46 to \% were obtained at feed concentrations of 200, 300 and $400 \mathrm{mg} / \mathrm{L}$, respectively. This shows that increased feed concentration decreased the percentage removal. Lower feed strengths favoured the $O \& G$ percentage reduction. In other words, the higher the feed strength, the shorter the time of saturation of the bed (Hernandez-Eudave et al., 2015; Nwabanne and Igbokwe, 2012; Sivakumar et al., 2010). Also higher adsorption time declined the O\&G removal. Similar observation was made by Umembamalu et al. (2020).

\section{$B$ - $A$ kinetic results}

Linear graphs of B-A model at varying CCAC sizes (Figure 9), bed heights (Figure 10) and feed strengths (Figure 11) were plotted. The values of the mass transfer coefficient, that 


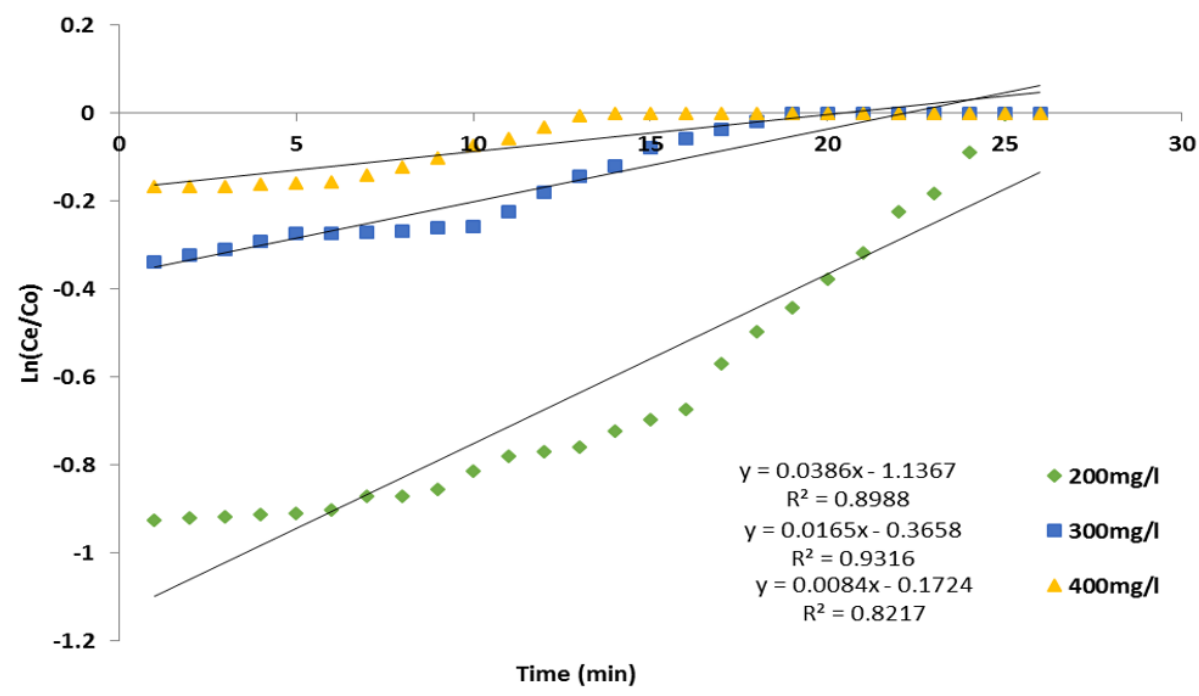

Figure 10. B-A kinetics for O\&G elimination onto CCAC: BH

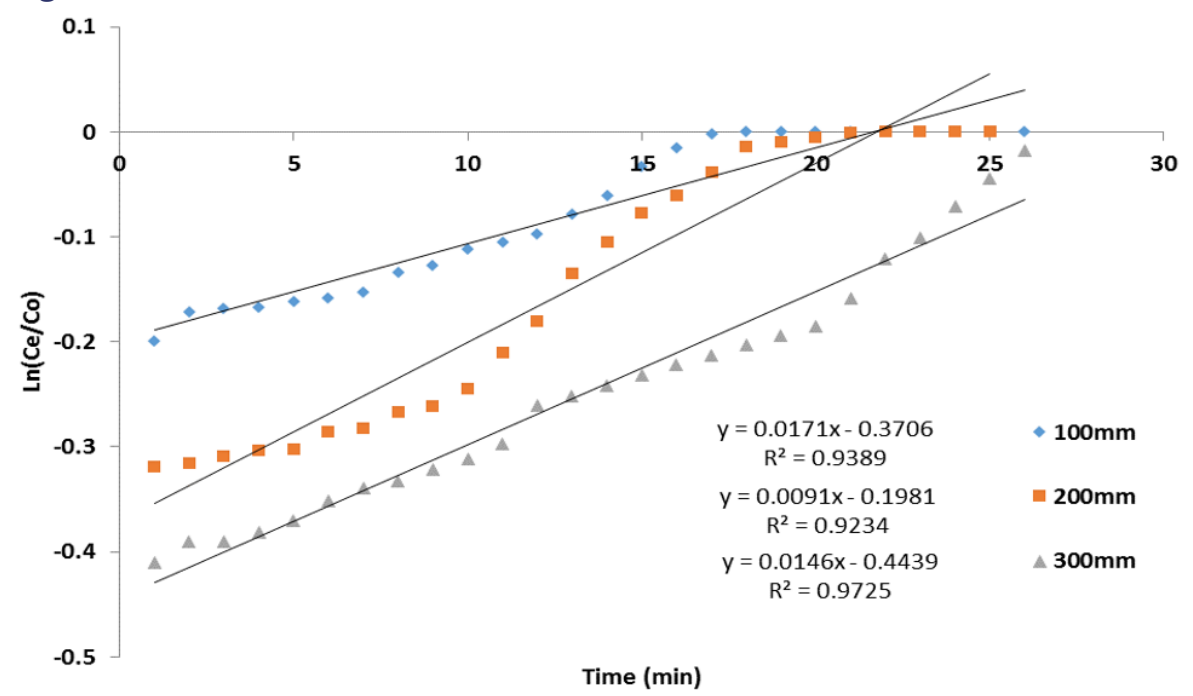

Figure 11. B-A kinetics for O\&G elimination onto CCAC: Effect of feed strength

Table 3. B-A parameters for $O \& G$ adsorption on CCAC

\begin{tabular}{cccccccccc} 
Kinetic & \multicolumn{3}{c}{ Particle size $(\mathbf{\mu m})$} & \multicolumn{4}{c}{ Initial feed concentration (mg/L) } & \multicolumn{3}{c}{ Bed height $(\mathbf{m m})$} \\
parameter & $\mathbf{1 5 0}$ & $\mathbf{3 0 0}$ & $\mathbf{6 0 0}$ & $\mathbf{2 0 0}$ & $\mathbf{3 0 0}$ & $\mathbf{4 0 0}$ & $\mathbf{1 0 0}$ & $\mathbf{2 0 0}$ & $\mathbf{3 0 0}$ \\
$K_{B A}(\mathrm{~L} / \mathrm{mg} \cdot \mathrm{min})$ & 500 & 367 & 200 & 1.93 & 0.55 & 0.21 & 0.3033 & 0.5667 & 0.4867 \\
x 10 & & & & & & & & & \\
$N_{0}(\mathrm{mg} / \mathrm{L})$ & 76780.05 & 62731.42 & 64518.05 & 2624.23 & 2963.42 & 3657.89 & 2908.74 & 2913.84 & 4063.84 \\
$\mathrm{R}^{2}$ & 0.9771 & 0.9353 & 0.8859 & 0.8988 & 0.9316 & 0.8217 & 0.9234 & 0.9389 & 0.9725
\end{tabular}

is, $K_{B A}$ and $N_{\mathrm{o}}$ were estimated from the linear plots using Eq. 5 and listed in Table 3. The $K_{B A}$, improved with BH. As the particle size decreased, $K_{A B}$ also decreased due to the reduction in the available adsorption sites, which is higher for small particles. Therefore at 150,300 , and $600 \mathrm{um}$, the $K_{B A}$ values were 500,367 , and $200 \mathrm{~mL} / \mathrm{min}$, respectively. As particle size increases, the adsorptive capacity decreases, as clearly outlined in Table 3; at $150 \mathrm{um}$, the $N_{\mathrm{o}}$ is $76780.048 \mathrm{mg} / \mathrm{L}$ and at $600 \mathrm{um}$, the $N_{\mathrm{o}}$ is $64518.053 \mathrm{mg} / \mathrm{L}$. The B-A model was used on the experimental data to describe the initial part of the breakthrough curves. The high regression $\left(\mathrm{R}^{2}\right)$ values shows a high degree of fit of the linear equations obtained, therefore the equations can be used to predict the breakthrough curve of any desired values. For the bed height, the adsorptive capacity or saturation capacity $\left(N_{\circ}\right)$ and the $K_{B A}$ increased with increasing $\mathrm{BH}$. The decrease in the $K_{B A}$ with increasing feed concentration suggests that the kinetics of the entire system is manipulated by the external mass transfer in the preliminary section of the adsorption column (De Franco et al., 2018; Gong et al., 2015). Similar pattern was observed by Yunnen et al. (2017).

\section{$Y$-N kinetic results}

The linear Y-N graphs at different particle sizes, BHs and feed concentrations are shown in Figures 12-14; $\tau$ and $K_{Y N}$ values are given in Table 4 . The $K_{Y N}$ improved with rising feed strength (Sivakumar and Palanisamy, 2009). The $K_{N Y}$ also improved with increasing particle size and decreasing BH. $\tau$ (period of breakthrough) declined with rising feed strength, particle size, and bed height. Similar behavior was observed by Kapur and Mondal (2015) and Bhaumik et al. (2013). 


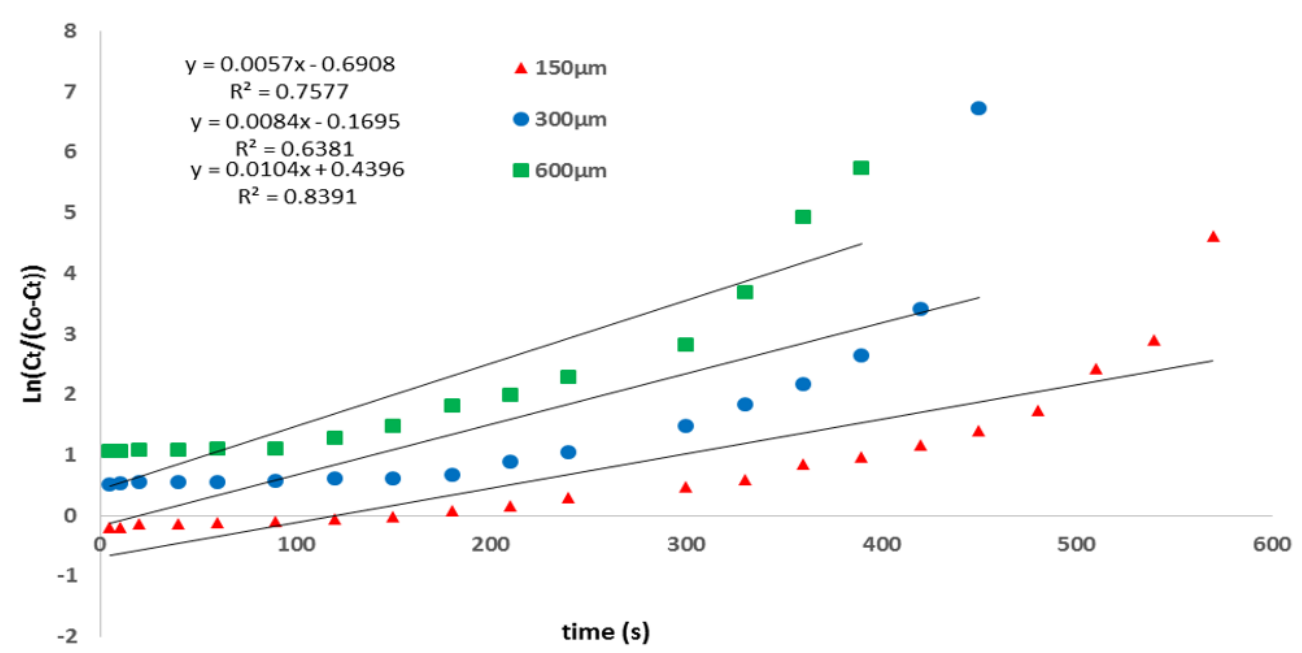

Figure 12. Y-N kinetics for O\&G elimination onto CCAC: Feed strength

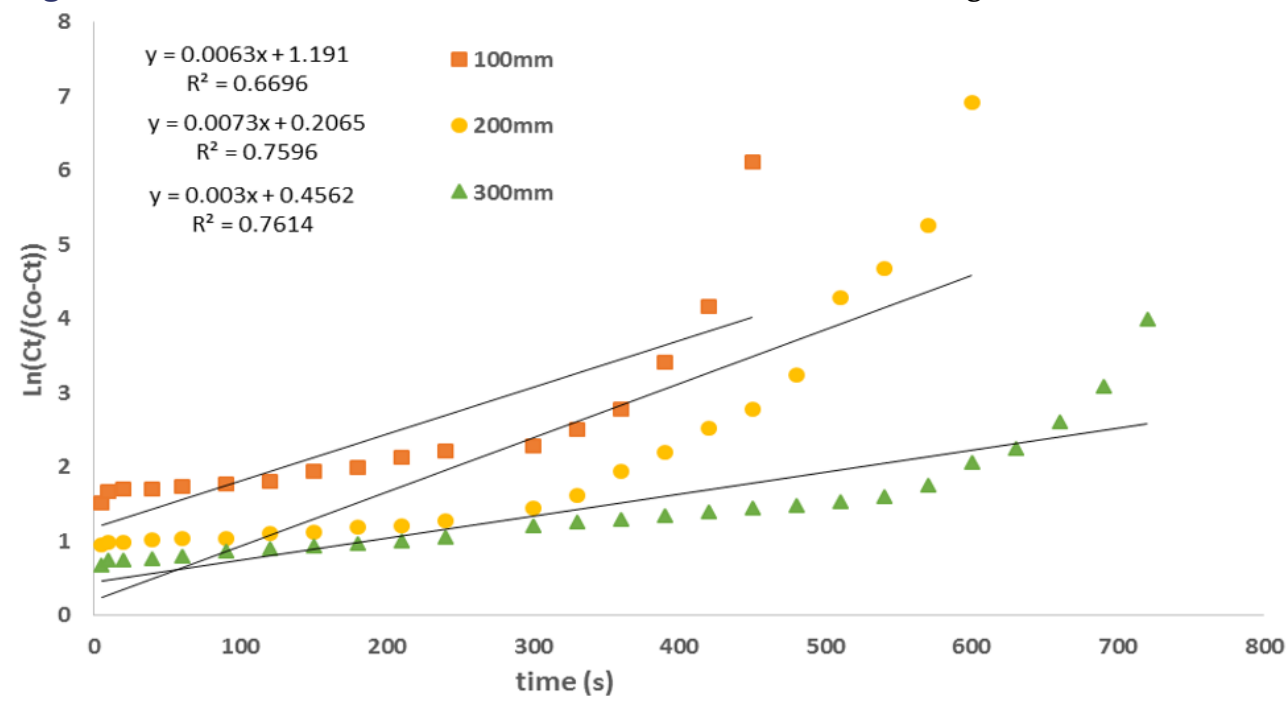

Figure 13. Y-N kinetics for O\&G elimination onto CCAC: $\mathrm{BH}$

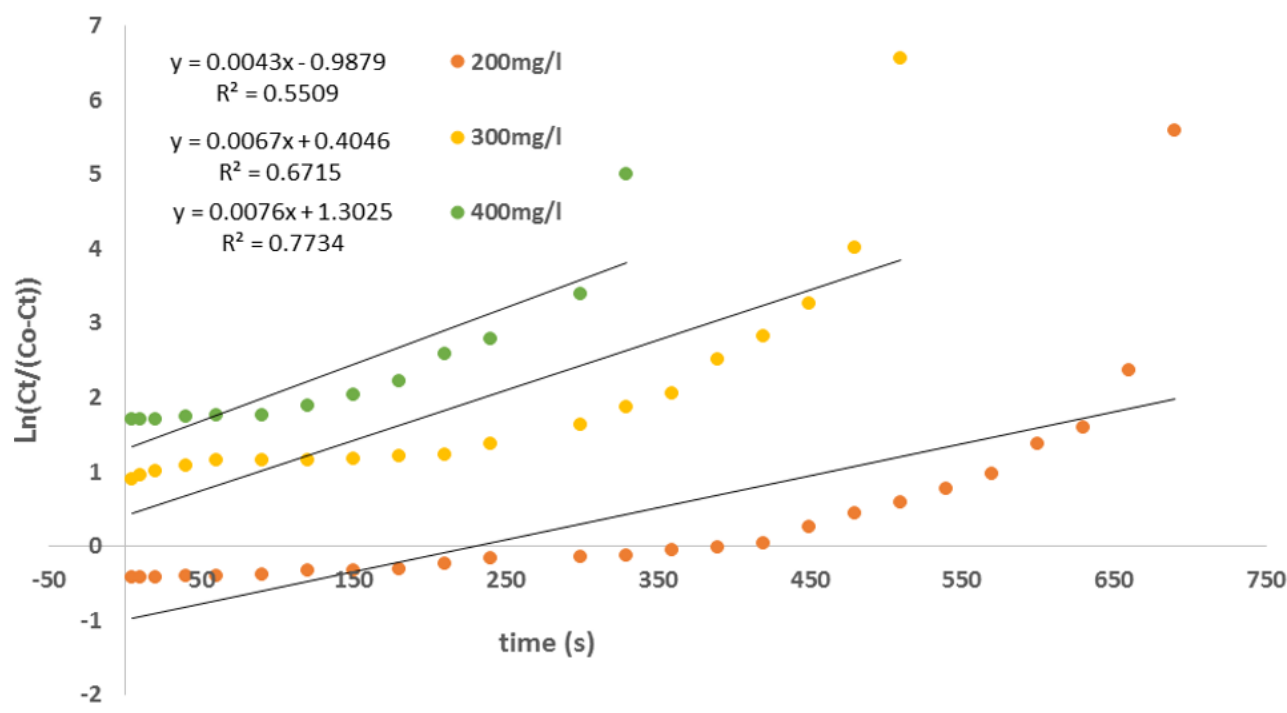

Figure 14. Y-N kinetics for O\&G elimination onto CCAC: Feed strength

The high values of correlation coefficients $\left(\mathrm{R}^{2}\right)$ for the B-A model (Table 3) in comparison to that of Y-N model (Table 4) points that the $\mathrm{B}-\mathrm{A}$ model fitted best to the $\mathrm{O} \& \mathrm{G}$ elimination on CCAC experimental data. Therefore, it means that the B-A model can be used to predict the breakthrough curve of any desired values for this study.

\section{The voidage of the packed bed}

Voidage or void fraction of the packed bed is such an important parameter of great concern during industrial adaptation that must be evaluated in column adsorption studies. This delivers key information on bed stability and data for the better modeling of this system (Willoughby et al., 2000). 
Table 4. Y-N parameters O\&G elimination on CCAC

\begin{tabular}{|c|c|c|c|c|c|c|c|c|c|}
\hline \multirow{2}{*}{$\begin{array}{c}\text { Kinetic } \\
\text { parameter }\end{array}$} & \multicolumn{3}{|c|}{ Particle size } & \multicolumn{3}{|c|}{ Initial feed concentration } & \multicolumn{3}{|c|}{ Bed height } \\
\hline & $150 \mu \mathrm{m}$ & $300 \mu \mathrm{m}$ & $600 \mu \mathrm{m}$ & $200 \mathrm{mg} / \mathrm{L}$ & $300 \mathrm{mg} / \mathrm{L}$ & $400 \mathrm{mg} / \mathrm{L}$ & $100 \mathrm{~mm}$ & $200 \mathrm{~mm}$ & $300 \mathrm{~mm}$ \\
\hline $\begin{array}{c}\mathrm{K}_{\mathrm{NY}}\left(\mathrm{min}^{-1}\right) \mathrm{x} \\
10^{-4}\end{array}$ & 57 & 84 & 104 & 43 & 67 & 76 & 63 & 73 & 30 \\
\hline$\tau(\min )$ & 121.193 & 80.178 & 42.269 & 229.7442 & 190.3881 & 171.382 & 189.048 & 168.288 & 152.067 \\
\hline $\mathrm{R}^{2}$ & 0.6381 & 0.7577 & 0.8391 & 0.5509 & 0.6715 & 0.7734 & 0.6696 & 0.7596 & 0.7614 \\
\hline
\end{tabular}

Table 5. Voidage of the packed bed, mass and volume of the CCAC at different BHs

\begin{tabular}{cccc}
\hline $\mathrm{BH}(\mathrm{m})$ & $M_{p}(\mathrm{~g})$ & $V_{p}\left(\mathrm{~m}^{3}\right)$ & $\varepsilon$ \\
\hline 0.1 & 0.692 & 0.0019 & 0.0247 \\
\hline 0.2 & 1.384 & 0.0038 & 0.0124 \\
\hline 0.3 & 2.075 & 0.0057 & 0.0082 \\
\hline
\end{tabular}

It could vary with the height of the bed. The void fractions $(\varepsilon)$ were evaluated at the different BHs studied (100, 200, and 300 $\mathrm{mm}$ ) using the following relationships (Eqs. 7-10) :

$$
\begin{gathered}
\varepsilon=\frac{V_{v}}{V_{T}} \\
V_{T}=B H \times A_{c} \\
V_{v}=V_{T}-V_{p} \\
V_{p}=\frac{M_{p}}{G_{p} \rho_{w}}
\end{gathered}
$$

Where $V_{v}$ is the void volume and $V_{T}$ is the total volume; $\mathrm{BH}$ is the packed bed height, $A_{c}$ is the cross-sectional area of column and $V_{p}$ is the volume of particles; $M_{p}$ is the mass of the CCAC particles at different $\mathrm{BHs}, G_{p}$ is the specific gravity of the CCAC $(0.365)$ and $\rho_{w}$ is the density of water.

The ideal residence time $\left(t_{R}\right)$ of the effluent in the adsorbent bed was evaluated using Eq. (11) (Michel et al., 2018):

$$
t_{R}=\frac{\varepsilon V_{T}}{Q}
$$

Where $Q$ is the volumetric feed flow rate.

The corresponding void fractions, mass of the CCAC measured, volume of particles and the residence time obtained at the different bed heights are shown in Table 5 . The void fraction $(\varepsilon)$ at BHs of 100, 200 and $300 \mathrm{~mm}$ were $0.0247,0.0124$ and 0.0082 , respectively. It was observed that the void fraction increased with increasing BH. Similar observation was made by Willoughby et al. (2000). Also, the masss and volume of CCAC in the packed bed was increased with $\mathrm{BH}$. Very low void fractions were obtained; this may be as a result of $150-600$ micron size particles been used for the study, so they could pack to form beds of very low voidage and such beds would offer enhanced resistance to liquid flow. The ideal residence time, $t_{R}$ was $4.49 \mathrm{~min}$.

\section{CONCLUSION}

The adsorption $O \& G$ from simulated refinery desalter effluent by activated carbon originated from chemical carbonization of corn cobs (CACC) has been investigated. The breakthrough time $(\tau)$ was observed to decrease with increasing particle size and feed $O \& G$ concentration (strength) while it increased with increasing BH. Maximum removals of 54.93, 37.28 and $25.63 \%$ were obtained for CCAC sizes of 150, 300 and $600 \mu \mathrm{m}$, respectively at constant BHs of $300 \mathrm{~mm}$ and feed concentration of $300 \mathrm{mg} / \mathrm{L}$. Maximum removals of 18.04, 27.97 and $33.66 \%$ were observed at $\mathrm{BH}$ of 100, 200 and $300 \mathrm{~mm}$, respectively at $5 \mathrm{~min}$, CCAC size of 300 $\mu \mathrm{m}$ and feed concentration of $300 \mathrm{mg} / \mathrm{L}$. Also, maximum removals of $60.38,28.76$ and 15.46 to \% were obtained at feed concentrations of 200,300 and $400 \mathrm{mg} / \mathrm{L}$, respectively at CCAC size of $300 \mu \mathrm{m}$ and $\mathrm{BH}$ of $300 \mathrm{~mm}$. The void fraction $(\varepsilon)$ at BHs of 100,200 and $300 \mathrm{~mm}$ were $0.0247,0.0124$ and 0.0082 , respectively. The residence time, $\boldsymbol{t}_{\boldsymbol{R}}$ was $4.49 \mathrm{~min}$. BohartAdams (B-A) and Yoon-and-Nelson (Y-N) equations were used to describe the fixed bed column kinetics/relationship between the operating factors. The saturation concentration $\left(N_{0}\right)$, and time required for $O \& G$ breakthrough $(\tau)$ were dependent on the feed concentration, particle size, and bed height $(\mathrm{BH})$. The $\mathrm{B}-\mathrm{A}$ best fitted the adsorptive elimination of $\mathrm{O} \& \mathrm{G}$ data than the Y-N model due to its high $\mathrm{R}^{2}$. This means that the $\mathrm{B}-\mathrm{A}$ model can be used to predict the breakthrough curve of any desired values for this study. The decrease in the B-A constant of kinetics $\left(K_{B A}\right)$ with increasing feed concentration suggests that the kinetics of the entire system is manipulated by the external mass transfer in the preliminary section of the adsorption column. Scale-up of the controlled parameters can satisfactorily be applied for industrial columns design.

\section{ACKNOWLEDGEMENTS}

This research is an undergraduate thesis submitted by Emmanuel Ugochukwu Osuagwu to Chemical Engineering Department, NAU, Awka, Nigeria, supervised by Engr. Dr. Chinenye Adaobi Igwegbe and Engr. C. J. Umembamalu. The authors wish to acknowledge Engr. Prof. J.T. Nwabanne for providing the required equipment and inspiration for this research. Our special thanks goes to Joshua O. Ighalo for his immense contributions.

\section{REFERENCES}

ABNT- Associação Brasileira de Normas Técnicas [Brazilian Association of Technical Standards]. NBR-14929 (2003) Madeira- Determinac,a o do Teor de Umidade em Cavacos - Me'todo por Secagem em Estufa [Madeira- Determination of the Moisture Content in Chips - Method by Kiln Drying]. Brazil. 
Adams, F. V., Hategekimana, F. and Sylvester, O. (2017). Crude oil contaminated water treatment: development of water filter from locally sourced materials. Procedia Manuf., 7, 465-447. https://doi.org/10.1016/j.promfg.2016.12.039

Afshin, P. and Toraj M. (2008). Wastewater treatment of desalting units. Desalination, 222, 249-254. https://doi.org/10.1016/j.desal.2007.01.166

Ahmadi, S. and Igwegbe, C. A. (2020). Removal of methylene blue on zinc oxide nanoparticles: nonlinear and linear adsorption isotherms and kinetics study. Sigma J. Eng. \& Nat. Sci., 38(1), 289-303.

Akoji, J. N. (2019). Adsorption performance of packed bed column for the removal of lead (11) using velvet tamarind (Dialium indum) Shells. Asian Journal of Applied Chemistry Research, 3(2), 1-14. https://doi.org/10.9734/ajacr/2019/ v3i230089

Alade, A. O., Jameel, A. T., Muyibi, S. A., Abdul Karim, M. I. and Alam, Md. Z. (2011). Application of semifluidized bed bioreactor as novel bioreactor system for the treatment of palm oil mill effluent (POME). African Journal of Biotechnology, 10(81), 18642-48648. https://doi.org/ 10.5897/AJB11.2767

Albadarin, A. B., Mangwandi, C., Al-Muhtaseb, A. H., Walker, G. M., Allen, S. J. And Ahmad, M. N. M. (2012). Modelling and fixed bed column adsorption of $\mathrm{Cr}(\mathrm{VI})$ onto orthophosphoric acid-activated lignin. Chin. J. Chem. Eng., 20(3), 469-477. https://doi.org/10.5897/AJB11.2767

Al-Kaabi, M. A., Al-Ghouti, M. A., Ashfaq, M. Y. M., Ahmed, T. and Zouari, N. (2019). An integrated approach for produced water treatment using microemulsions modified activated carbon. Journal of Water Process Engineering, 31, 100830. https://doi.org/10.1016/j.jwpe.2019.100830

Al-Malack, M. and Siddique, M. (2013). Treatment of synthetic petroleum refinery wastewater in a continuous electrooxidation process. Desal. Water Treat., 51, 34-36. https://doi.org/10.1080/19443994.2013.767215

Ariana, M. P., Vitor, J. V., Cidảlia, M. B. and Rui, A. B. (2016). Oil and grease removal from wastewaters: Sorption treatment as alternative to state-of-art technologies. A critical review. Chem. Eng. J., 229-255. https://doi.org/10.1016/j.cej.2016.03.121

Baseri, J., Palanisamy, P. and Sivakumar, P. (2012). Preparation and characterization of activated carbon from Thevetia peruviana for the removal of dyes from textile waste water. Advances in Applied Science Research, 3(1), 377-383.

Batool F., Akbar J., Iqbal S., Noreen S. and Bukhari, S. N. A. (2018). Study of isothermal, kinetic, and thermodynamic parameters for adsorption of cadmium: an overview of linear and nonlinear approach and error analysis. Bioinorganic Chemistry and Applications, 3463724, 11 pages. https://doi.org/10.1155/2018/3463724

Bharathi, K. S. and Ramesh, S. T. (2013). Removal of dyes using agricultural waste as low-cost adsorbents: a review. Appl Water Sci, 3, 773-790 https://doi.org/10.1007/s13201-0130117-y
Bhaumik, M. Setshedi, K., Maity, A. and Onyango, M. S. (2013) Chromium(VI) removal from water using fixed bed column of polypyrrole/Fe $\mathrm{F}_{3} \mathrm{O}_{4}$ nanocomposite. Sep. Purif. Technol. 110, 11-19. https://doi.org/10.1016/j.seppur.2013.02.037

Boni, H. T., de Oliveira, D., Ulson de Souza, A. A. and Ulson de Souza, S. M. A. G. (2016). Bioadsorption by sugarcane bagasse for the reduction in oil and grease content in aqueous effluent. Int. J. Environ. Sci. Technol. 13, 11691176. https://doi.org/10.1007/s13762-016-0962-y

Borhan, A., Phoon, K. H. and Taha, M. F. (2014). Biosorption of heavy metal 1ons, oil and grease from industrial waste water by banana peel. Applied Mechanics and Materials, 625, 749-752. https://doi.org/10.4028/www.scientific.net/ amm.625.749

Bulgariu, D. and Bulgariu, L. (2013). Sorption of $\mathrm{Pb}(\mathrm{II})$ onto a mixture of algae waste biomass and anion exchanger resin in a packed-bed column. Bioresour. Technol., 129, 374-380. https://doi.org/10.1016/j.biortech.2012.10.142

Choi, H.-J. (2019). Agricultural bio-waste for adsorptive removal of crude oil in aqueous solution. J. Mater. Cycles Waste, 21(2), 356-364. https://doi.org/10.1007/s10163018-0797-3

Choi, H-J. and Yu, S-W. (2019). Biosorption of methylene blue from aqueous solution by agricultural bioadsorbent corncob. Environmental Engineering Research, 24(1), 99106. https://doi.org/10.4491/eer.2018.107

Dada, A., Inyinbor, A. and Oluyori, A. (2012). Comparative adsorption of dyes unto activated carbon prepared from maize stems and sugar cane stems. Journal of Applied Chemistry, 2(3), 38-43. https://doi.org/10.9790/57360233843

Dai, Y., Sun, Q., Wang, W., Lu, L., Liu, M., Li, J. ... Zhang, Y. (2018). Utilizations of agricultural waste as adsorbent for the removal of contaminants: A review. Chemosphere, 211, 235-253.

https://doi.org/10.1016/j.chemosphere.2018.06.179

De Franco, M. A. E., de Carvalho, C. B., Bonetto, M. M., de Pelegrini Soares, R. and Féris, L. A. (2018). Diclofenac removal from water by adsorption using activated carbon in batch mode and fixed-bed column: Isotherms, thermodynamic study and breakthrough curves modeling. J. Clean. Prod., 181, 145-154. https://doi.org/10.1016/ j.jclepro.2018.01.138

Devi, B. V., Jahagirdar, A. and Ahmed, M. (2012). Adsorption of chromium on activated carbon prepared from coconut shell. International Journal of Engineering Research and Applications (IJERA), 2(5), 364-370.

Diraki, A., Mackey, H. R., McKay, G. And Abdala, A. (2019). Removal of emulsified and dissolved diesel oil from high salinity wastewater by adsorption onto graphene oxide. $J$. Environ. Chem. Eng., 7(3), 103106. https://doi.org/10.1016/ j.jece.2019.103106

Dutta, M. and Basu, J. K. (2014). Fixed-bed column study for the adsorptive removal of acid fuchsin using carbonalumina composite pellet. Int. J. Environ. Sci. Technol., 11, 87-96. https://doi.org/10.1007/s13762-013-0386-x 
Egwaikhide, P., Akporhonour, E. and Okieimen, F. (2007). Utilization of coconut fibre carbon in the removal of soluble petroleum fraction polluted water. International Journal of Physical Sciences, 2(2), 47-49.

Facchin, S., Alves, P. D. D., de Faria, S. F., Tatiana, M. B., Júnia, M. N. V. and Evanguedes, K. (2013). Biodiversity and secretion of enzymes with potential utility in wastewater treatment. Open Journal of Ecology, 3(1), 34-47. https://doi.org/10.4236/oje.2013.31005

Fulazzaky, M. A. and Omar, R. (2012). Removal of oil and grease contamination from stream water using the granular activated carbon block filter. Clean Technol. Environ. Policy, 14(5), 965-971. https://doi.org/10.1007/ s10098-012-0471-8

Goel, J., Kadirvelu, K., Rajagopal, C., and Garg, V. K. (2005). Removal of lead(II) by adsorption using treated granular activated carbon: Batch and column studies. J. Hazard. Mater., 125(1-3), 211-220. https://doi.org/10.1016/ j.jhazmat.2005.05.032

Gong, J. L., Zhang, Y. L., Jiang, Y., Zeng, G. M., Cui, Z. H., Liu, K. ... Huan, S. Y. (2015). Continuous adsorption of Pb(II) and methylene blue by engineered graphite oxide coated sand in fixed-bed column. Appl. Surf. Sci. 330, 148-157. https://doi.org/10.1016/j.apsusc.2014.11.068

Grieves, C., Crame, L., Venardos, D. and Ying, W. (1980). Powdered versus granular carbon for oil refinery wastewater treatment. Journal (Water Pollution Control Federation), 52(3), 483-497.

Hamid, N. S. A., Malek, N. A. C, Mokhtar, H., Mazlan, W. S. And Tajuddin, R. M. (2016). Removal of oll and grease from wastewater using natural adsorbents. Jurnal Teknologi, 78, 5-3, 97-102. https://doi.org/10.11113/jt.v78.8519

Hernandez-Eudave, M. T., Bonilla-Petriciolet, A., MorenoVirgen, M. R., Rojas-Mayorga, C. K. and TovarGómez, R. (2015). Design analysis of fixed-bed synergic adsorption of heavy metals and acid blue 25 on activated carbon. Desal. Water Treat., 57(21), 9824-9836. https://doi.org/10.1080/ 19443994.2015.1031710

Ighalo, J. O. and Adeniyi, A. G. (2020) A Comprehensive Review of Water Quality Monitoring and Assessment in Nigeria, Chemosphere, 260, 127569 https://doi.org/10.1016/ j.chemosphere.2020.127569

Ighalo, J. O., Ajala, O. J., Umenweke, G., Ogunniyi, S., Adeyanju, C. A., Igwegbe, C. A. and Adeniyi, A. G. (2020). Mitigation of clofibric acid pollution by adsorption: A review of recent developments, J. Environ. Chem. Eng., 8(5), 104264. https://doi.org/10.1016/j.jece.2020.104264

Igwegbe, C. A, Onukwuli, O. D., Onyechi, K. K. and Ahmadi, S. (2020). Equilibrium and kinetics analysis on Vat Yellow 4 uptake from aqueous environment by modified rubber seed shells: nonlinear modelling. J. Mater. Environ. Sci., 11(9) 1424-1444.

Igwegbe, C. A., Banach, A. M. And Ahmadi, S. (2018). Adsorption of Reactive Blue 19 from aqueous environment on magnesium oxide nanoparticles: kinetic, isotherm and thermodynamic studies, The Pharmaceutical and Chemical Journal, 5, 111-121.
Igwegbe, C. A., Onukwuli, O. D. and Nwabanne, J. T. (2016). Adsorptive removal of vat yellow 4 on activated Mucuna pruriens (velvet bean) seed shells carbon. Asian J. Chem. Sci., 1(1), 1-16. https://doi.org/10.9734/AJOCS/2016/30210

Igwegbe, C. A., Onyechi, P. C. and Onukwuli, O. D. (2015). Kinetic, isotherm and thermodynamic modelling on the adsorptive removal of malachite green on Dacryodes edulis seeds. J. Sci. Eng. Res., 2, 23-39.

Islam, M. S., Saiful, M., Hossain, M., Sikder, M., Morshed, M. And Hossain, M. (2013). Acute toxicity of the mixtures of grease and engine wash oil on fish, pangasius sutch, under laboratory condition. International Journal Life Science, Biotechnology and Pharmacology Research, 2(1), 306-317.

Janani, T., Sudarsan, J. and Prasanna, K. (2019). Grey water recycling with corn cob as an adsorbent. Paper presented at the AIP Conference Proceedings. https://doi.org/ 10.1063/1.5112366

Jmaa, S. B. and Kallel, A. (2019). Assessment of Performance of Posidona oceanica (L.) as biosorbent for crude oil-spill cleanup in seawater. BioMed Research International, Article ID 6029654. https://doi.org/10.1155/2019/6029654

Kapur M. and Mondal, M. K. (2015). Design and model parameters estimation for fixed-bed column adsorption of $\mathrm{Cu}$ (II) and $\mathrm{Ni}(\mathrm{II})$ ions using magnetized saw dust. Desal. Water Treat., 57(26), 12192-12203. https://doi.org/10.1080 /19443994.2015.1049961

Kavak, D. and Öztürk, N. (2004). Adsorption of boron from aqueous solution of sepirolite: II. Column studies. Uluslararasi Bor. Sempozyumu, 23-25, 495-500.

Kulkarni, S. J. (2016). An insight into oil and grease removal from wastewater from petroleum and refinery industries. International Journal of Petroleum and Petrochemical Engineering (IJPPE), 2(1), 12-15. https://doi.org/10.20431/ 2454-7980.0201003

Kulowiec, J. J. (1979). Techniques for removing oil and grease from industrial wastewater. United States.

Malode, M. P. P. and Mamilwar, M. B. (2017). Case study on removal of ambazari lake water impurities by using corn cob and neem leaves as bio-adsorbents. Int. Journal of Engineering Research and Application, 7(3), 60-61. https://doi.org/10.9790/9622-0703066061

Manilal, A., Soloman, P. and Basha, C. A. (2020). Removal of oil and grease from produced water using electrocoagulation. J. Hazard. Toxic Radioact. Waste, 24(1), 04019023. https://doi.org/10.1061/(ASCE)HZ.2153-5515.0000463

Mazumder, D. and Mukherjee, S. (2011). Treatment of automobile service station wastewater by coagulation and activated sludge process. Int. J. Environ. Sci. Dev., 2(1), 6469. https://doi.org/10.7763/IJESD.2011.V2.98

Michel, C., Barré, Y., Guiza, M., de Dieuleveult, C., de Windt, L., et al. (2018). Breakthrough studies of the adsorption of Cs from freshwater using a mesoporous silica material containing ferrocyanide. Chem. Eng. J., 339, 288-295. https://doi.org/10.1016/j.cej.2018.01.101

Muthusamy, P. and Murugan, S. (2016). Removal of lead ion using maize cob as a bioadsorbent, Int. Journal of Engineering Research and Application, 6(6), 5-10. 
Nadzirah, Z., Nor Haslina, H. and Mohd Adib, M. R. (2015). Studies on the preparation of activated carbon sugarcane bagasse on removal of chemical oxygen demand, alkalinity and oil and grease of car wash wastewater. Advances in Environmental Biology, 9(12), 15-20.

Norozi, F. and Haghdoost, G. (2016). Application of corncob as a natural adsorbent for the removal of Mn (VII) ions from aqueous solutions. Orient. J. Chem., 32(4), 2263-2268. https://doi.org/10.13005/ojc/320460

Nwabanne, J. T. and Igbokwe, P. K. (2012). Adsorption performance of packed bed column for the removal of lead (ii) using oil palm fibre. International Journal of Applied Science and Technology, 2(5), 106-115.

Nwabanne, J. T., Okoye, A. C. and Lebele-Alawa, T. (2011). Packed bed column studies for the removal of lead (II) using oil palm empty fruit bunch. Eur. J. Sci. Res., 63(2), 296-305.

Onyechi, C. A. (2014). Textile wastewater treatment using activated carbon from agro wastes (M. Eng. Thesis), Department of Chemical Engineering, Nnamdi Azikiwe University, Awka, Nigeria.

Pintor, A. M., Vilar, V. J., Botelho, C. M. and Boaventura, R. A. (2016). Oil and grease removal from wastewaters: sorption treatment as an alternative to state-of-the-art technologies. A critical review. Chem. Eng. J., 297, 229-255. https://doi.org/10.1016/j.cej.2016.03.121

Rahmat, S. N., Adel Ali Saeed Abduh, A., Mohd Ali, A. Z., Mohammad Razi, M. A. and Adnan, M. S. (2018). Field performance of a constructed litter trap with oil and grease filter using low-cost materials. International Journal of Integrated Engineering, 10(2). https://doi.org/10.30880/ ijie.2018.10.02.024

Rahmat, S. N., Ali, A. Z. M., Ibrahim, M. H. W. and Alias, N. A. (2017). Oil and grease (O\&G) removal from commercial kitchen waste water using carbonised grass as a key media. MATEC Web of Conferences, 87, 01010. https://doi.org/10.1051/matecconf/20178701010

Rao, K. S. (2011). Modeling the kinetics of Cd(II) adsorption on Syzygium cumini L leaf powder in a fixed bed mini column. J. Ind. Eng. Chem., 17(2), 25, 174-181. https://doi.org/ 10.1016/j.jiec.2011.02.003

Rashed, M. N. (2013). Adsorption technique for the removal of organic pollutants from water and wastewater. Organic pollutants - monitoring, risk and treatment. IntechOpen. https://doi.org/10.5772/54048

Rengaraj, S., Moon, S., Sivabalan, R., Arabindoo, B. and Murugesan, V. (2002). Removal of phenol from aqueous solution and resin manufacturing industry wastewater using an agricultural waste: rubber seed coat. J. Hazard. Mater., 89(2-3), 185-196.

Sasirekha, P., Balaji, A. K., Amarnath, H. and Balasubramaniyan, A. L. (2018). Removal of oil and grease from wastewater by using natural adsorbent. International Journal of Applied Engineering Research, 13(10), 7246-7248.

Seader, J., Hanley, E. and Roper, K. (2011). Separation process principle (3rd Ed.). John Wiley and Sons, Inc.
Sharma, A., Tomer, A., Singh, J. And Chhikara, B. S. (2019). Biosorption of metal toxicants and other water pollutants by corn (maize) plant: A comprehensive review. Journal of Integrated Science and Technology, 7(2), 19-28.

Sivakumar, B., Karthikeyan, S. And Kannan, C. (2010). Film and pore diffusion modelling for the adsorption of direct red 81 on activated carbon prepared from balsamodendron caudatum wood waste. Digest Journal of Nanomaterials and Biostructures, 5(3), 657-665.

Sivakumar, P. and Palanisamy, P. (2009). Adsorption studies of basic Red 29 by a non-conventional activated carbon prepared from Euphorbia antiquorum L. International Journal of Chem. Tec. Research, 1(3), 502-510.

Song, W., Xu, X., Tan, X., et al. (2015). Column adsorption of perchorate by amine-crosslinked biopolymer based resin and its biological, chemical regeneration properties. Carbohydrates Polymers, 432-438. https://doi.org/10.1016/ j.carbpol.2014.09.010

Swarup, B. and Mishra, U. (2015). Continuous fixed-bed column study and adsorption modeling: removal of lead ion from aqueous solution by charcoal originated from chemical carbonization of rubber wood sawdust. Journal of Chemistry. https://doi.org/10.1155/2015/907379

Umembamalu, C. J., Igwegbe, C. A., Osuagwu, E. U. and Nwabanne, J. T. (2020). Packed bed column adsorption of oil and grease from refinery desalter effluent, using rice husks derived carbon as the adsorbent: Influence of process parameters and Bohart-Adams kinetics study. World News of Natural Sciences, 31, 155-174.

Vu, M. T., Chao, H.-P., Van Trinh, T., Le, T. T., Lin, C.-C. and Tran, H. N. (2018). Removal of ammonium from groundwater using $\mathrm{NaOH}$-treated activated carbon derived from corncob wastes: Batch and column experiments. $J$. Clean. Prod., 180, 560-570. https://doi.org/10.1016/ j.jclepro.2018.01.104

Willoughby, N. A. Hjorth, R. and Titchener-Hooker, N. J. (2000). Experimental measurement of particle size distribution and voidage in an expanded bed adsorption system. Biotechnol. Bioeng., 69(6), 648-653. https://doi.org/ 10.1002/1097-0290(20000920)69:6<648::AID-BIT9>3.0. $\mathrm{CO} ; 2-\mathrm{U}$

Yalcinkaya, F., Boyraz, E., Maryska, J. and Kucerova, K. (2020). A review on membrane technology and chemical surface modification for the oily wastewater treatment. Materials (Basel), 13(2), 493. https://doi.org/10.3390/ma13020493

Younis, S.A., El-Salamonyc, R. A., Tsang, Y. F., Kim, K-H., (2020). Use of rice straw-based biochar for batch sorption of barium/strontium from saline water: Protection against scale formation in petroleum/desalination industries. $J$. Clean. Prod., 250, 119442. https://doi.org/10.1016/ j.jclepro.2019.119442

Yunnen, C., Ye, W., Chen, L., Lin, G., Jinxia, N. and Rushan, R. (2017). Continuous fixed-bed column study and adsorption modeling: removal of arsenate and arsenite in aqueous solution by organic modified spent grains. Pol. J. Environ. Stud., 26(4), 1847-1854. https://doi.org/10.15244/pjoes/ 68869 
Zhang, X., Wang, X. And Chen, Z. (2017). A novel nanocomposite as an efficient adsorbent for the rapid adsorption of Ni (II) from aqueous solution, Materials, 10, 1124. https://doi.org/10.3390/ma10101124 